\title{
STRATEGI MARKETING PENERIMAAN MAHASISWA BARU UNIVERSITAS SANGGABUANA BANDUNG DITENGAH PANDEMI COVID 19
}

\author{
Y. Ony Djogo \\ ony.djogo@usbypkp.ac.id \\ Universitas Sanggabuana YPKP
}

\begin{abstract}
Indeed, currently we are experiencing a difficult situation, but the process of admitting new students must also continue for the sustainability of the campus and also learning in Indonesia, especially on USB. With campus technology, it can facilitate the admission of new students, provide sophisticated services, such as PMB, payments, academics, learning etc. After simplifying the process of receiving and payment, what to do next is Promotion. Because in the current situation conventional promotion is not possible, one solution is to take advantage of digital technology that is easily accessible to many people. Here's what can be done with promotion with digital marketing: Use the website to be recognized more quickly, Make video ads on YouTube, Content marketing and SEO optimization, Take advantage of the campus search platform.
\end{abstract}

Keywords: Marketing Strategy, New Student Admission, Covid-19

Memang saat ini kita sedang mengalami situasi yang sulit, namun proses penerimaan mahasiswa baru juga harus terus berjalan demi keberlangsungan kampus dan juga pembelajaran di Indonesia khususnya di USB. Dengan teknologi kampus bisa memudahkan penerimaan mahasiswa baru, memberikan pelayanan yang serba canggih, seperti PMB, pembayaran, keakademikan, pembelajaran dll. Setelah mempermudah proses penerimaan dan pembayaran, yang harus dilakukan selanjutnya adalah Promosi. Karena di situasi sekarang promosi dengan konvensional tidak memungkinkan, salah satu solusinya adalah memanfaatkan teknologi digital yang mudah dijangkau oleh banyak orang. Berikut yang bisa dilakukan dengan promosi dengan digital marketing: Gunakanlah website agar lebih cepat dikenal, Buatlah iklan video di youtube, Konten marketing dan SEO optimasi, Manfaatkan platform pencarian kampus.

Kata kunci : Strategi Marketing, Penerimaan Mahasiswa Baru, Covid-19

\section{PENDAHULUAN}

Perusahaan dalam menjalankan aktivitasnya baik perusahaan yang bergerak dalam bidang jasa maupun barang mempunyai tujuan yang sama yaitu memperoleh keuntungan. Selain itu perusahaan juga ingin memberikan kepuasan kepada konsumen atas produk yang yang dihasilkannya, karena kepuasan konsumen menjadi tolak ukur dari keberhasilan perusahaan dalam menghasilkan produk yang berkualitas, dan yang diinginkan oleh konsumen. 
Dalam mencapai strategi pemasaran yang tepat dan terbaik untuk diterapkan, salah satunya perusahaan dapat melihat dari faktor bauran pemasaran. Hal tersebut penting karena bauran pemasaran merupakan salah satu pokok pertimbangan konsumen dalam melakukan keputusan pembelian suatu produk. Jika perusahaan tidak peka terhadap apa yang dibutuhkan oleh konsumen, maka dapat dipastikan bahwa perusahaan akan kehilangan banyak kesempatan untuk menjaring konsumen dan produk yang ditawarkan akan sia-sia.

Pemasaran merupakan salah satu ilmu ekonomi yang telah lama berkembang, dan sampai pada saat sekarang ini pemasaran sangat mempengaruhi keberhasilan suatu perusahaan untuk bisa bertahan di dalam pangsa pasar. oleh karena itu diperlukan strategi pemasaran yang dapat memberikan pengaruh untuk menentukan berhasil atau tidaknya dalam memasarkan produknya. Apabila strategi pemasaran yang dilaksanakan perusahaan tersebut mampu memasarkan produknya dengan baik, hal ini akan berpengaruh terhadap tujuan perusahaan.

Sebagaimana diketahui bahwa keadaan dunia usaha bersifat dinamis, yang selalu mengalami perubahan yang terjadi setiap saat dan adanya keterkaitan antara satu dengan yang lainnya. Oleh karena itu strategi pemasaran mempunyai peranan yang sangat penting untuk keberhasilan perusahaan umumnya dan pada bidang pemasaran khususnya. Disamping itu strategi pemasaran yang diterapkan harus ditinjau dan dikembangkan sesuai dengan perkembangan pasar dan lingkungan pasar tersebut. Dengan demikian strategi pemasaran harus dapat memberikan gambaran yang jelas dan terarah tentang apa yang dilakukan perusahaan dalam menggunakan setiap kesempatan atau paduan pada beberapa sasaran pasar.

Wabah Covid-19 berpotensi mengubah tatanan ekonomi dunia yang ditandai dengan berubahnya peta perdagangan dunia, selain mengakibatkan mandegnya berbagai bidang usaha. Corona Virus Disease 2019 (COVID-19) telah dinyatakan oleh WHO sebagai pandemic dan Pemerintah Indonesia berdasarkan Keputusan Presiden Nomor 11 Tahun 2020 tentang Penetapan Kedaruratan Kesehatan Masyarakat Corona Virus Disease 2019 (COVID-19) telah menyatakan COVID-19 sebagai kedaruratan kesehatan masyarakat yang wajib dilakukan upaya penanggulangan.

World Health Organization (WHO) memberi nama virus baru tersebut Severe acute respiratory syndrome coronavirus- 2 (SARS-CoV-2) dan nama penyakitnya sebagai penyeakitnya disebut Coronavirus Disease (COVID-19). Pada mulanya transmisi virus ini belum dapat ditentukan apakah dapat melalui antara manusia- 
manusia. Jumlah kasus terus bertambah seiring dengan berjalannya waktu. Akhirnya dikonfirmasi bahwa transmisi pneumonia ini dapat menular dari manusia ke manusia. Sampai saat ini virus ini dengan cepat menyebar masih misterius dan berbagai penelitian masih berlanjut.

Sebagaimana kita ketahui bahwa produk ataupun jasa yang dihasilkan oleh perusahaan tidak mungkin dapat mencari sendiri pembeli ataupun peminatnya. 0leh karena itu, produsen dalam kegiatan pemasaran produk atau jasanya harus membutuhkan konsumen mengenai produk atau jasa yang dihasilkannya.Suatu produk tidak akan dibeli bahkan dikenal apabila konsumen tidak mengetahui kegunaannya, keunggulannya, dimana produk dapat diperoleh dan berapa harganya. Untuk itulah konsumen yang menjadi sasaran produk atau jasa perusahaan perlu diberikan informasi yang jelas.

Disamping itu strategi pemasaran yang diterapkan harus ditinjau dan dikembangkan sesuai dengan perkembangan pasar dan lingkungan pasar tersebut. Dengan demikian strategi pemasaran harus dapat memberikan gambaran yang jelas dan terarah tentang apa yang dilakukan perusahaan dalam menggunakan setiap kesempatan atau paduan pada beberapa sasaran pasar.

Strategi pemasaran merupakan salah satu cara dalam mengenalkan produk kepada konsumen, dan hal ini menjadi penting karena akan berhubungan dengan laba yang akan dicapai oleh perusahaan. Strategi pemasaran akan berguna secara optimal bila didukung oleh perencanaan yang terstruktur baik dalam segi internal maupun eksternal perusahaan.

Dalam ilmu pemasaran, sebelum melakukan berbagai macam promosi atau pendekatan pemasaran lainnya, perusahan harus terlebih dahulu membidik pasar atau segmen secara jelas. Sebagian besar kegagalan usaha yang terjadi disebabkan oleh gagalnya perusahaan mendefenisikan pasar yang dituju dan bagaimana potensinya.

Dengan banyaknya jumlah konsumen dan keanekaragaman keinginan pembelian menyebabkan perusahaan tidak dapat memasuki semua segmen pasar, perusahaan harus dapat mengidentifikasi segmen pasar yang dapat dilayani paling efektif, yaitu dengan melakukan penelitian segmentasi, khususnya Strategi Marketing PMB USB Ditengah Pandemi Covid 19.

\section{KERANGKA TEORI}

\section{A. Strategi Pemasaran}

Pemasaran adalah suatu proses sosial manajerial di mana individu dan kelompok mendapatkan kebutuhan dan keinginan mereka dengan menciptakan, menawarkan dan bertukar sesuatu yang bernilai satu sama lain. Definisi ini berdasarkan pada 
konsep inti, yaitu: kebutuhan, keinginan dan permintaan; pasar, pemasaran dan pemasar.

Tujuan Pemasaran adalah mengenal dan memahami pelanggan sedemikian rupa sehingga produk yang di jual akan cocok sesuai dengan keinginan pelanggan,sehingga produk tersebut dapat terjual dengan sendirinya. Idealnya pemasaran menyebabkan pelanggan siap membeli sehingga yang harus di fikirkan selanjutnya adalah bagaimana membuat produk tersebut tersedia.

Strategi pemasaran pada hakikatnya merupakan serangkaian upaya yang ditempuh dalam rangka mencapai tujuan tertentu. Untuk kepentingan kita dalam merancang strategi pemasaran, kita akan berpijak pada pengertian strategi pemasaran yang disampaikan oleh William Zikmund dan Michael D'Amico.

Pengertian strategi pemasaran menurut William Zikmund dan Michael D'Amico adalah serangkaian upaya yang ditempuh dalam rangka mencapai tujuan tertentu. Dalam mengembangkan suatu pemasaran, setiap langkah yang dilakukan dalam memformulasikan strategi pemasaran harus diorientasikan pada upaya untuk mencapai kepuasan pelanggan. Kepuasan pelanggan merupakan kunci utama dari konsep pemasaran dan strategi pemasaran. Ini berarti bahwa proses yang ditempuh oleh setiap pihak boleh jadi bermacam-macam sesuai dengan kesanggupan dan karakteristik masingmasing tetapi tujuan akhirnya tetap akan bermuara pada tercapainya kepuasan konsumen atau consumer satisfaction McCarthy dkk (1998).

Fungsi utama mengapa kegiatan pemasaran dilakukan: 1) Untuk memberikan informasi tentang produk yang dijual perusahaan; 2) Untuk mempengaruhi keputusan membeli konsumaen; dan 3) Untuk menciptakan nilai ekonomis suatu barang.

\section{B. Strategi Produk}

Produk (Product) adalah tawaran untuk memuaskan kebutuhan dari perusahaan.

Tawaran ini dapat berbentuk barang, jasa, atau campuran keduanya. Produk menggambarkan bagaimana perusahaan menciptakan produk yang tepat untuk pasar sasaran. Berkaitan dengan produk adalah pemberian merek, pengemasan, jaminan, pengembangan produk baru, kualitas produk dan lini produk yang ada.

Ada 3 bagian yang harus diperhatikan dalam strategi produk yaitu:

\section{Pemilihan barang/produk}

Kebijaksanaan perusahaan dalam memilih produk yang akan dijual atau produk yang akan dibeli (bagi perusahaan dagang) amat berpengaruh pada penentuan harga, strategi, promosi, yang akan dilakukan agar berhasil dalam 
melaksanakan fungsi penjualan dari bidang pemasaran. Pemilihan barang atau produk yang tepat untuk dipasarkan atau sesuai dengan perilaku pembeli ataupun daya beli konsumen akan menguntungkan perusahaan sehingga hasil kegiatan perusahaan yang dicapai akan dapat mempertahankan atau ditingkatkan demi kelangsungan hidup perusahaan.

Sebelum perusahaan terlambat dalam mengatasi perjalanan produk dalam siklus kehidupan produk maka tindakan yang harus dilakukan adalah strategi apa yang akan dilakukan atau kebijaksanaan apa yang akan dilakukan agar sebelum produk tersebut sudah tidak laku lagi perusahaan sudah menyiapkan produk baru,sebagai pengganti atau strategi baru.

Tahap-tahap siklus kehidupan dibagi menjadi 5 tahapan di mana untuk masingmasing tahap suatu perusahaan harus memasang strategi atau kebijaksanaan yang berlainan untuk menjaga agar kelangsungan hidup perusahaan terjamin.

Lima tahap tersebut adalah sebagai berikut :

\section{a. Tahap Perkenalan}

Tahap perkenalan ini menunjukan bahwa barang yang dipasarkan benar-benar baru atau masyarakat belum tahu atau belum mengenalnya sehingga perlu memperkenalkan barang tersebut pada masyarakat melalui penyampaian informasi dengan kegiatan promosi yang gencar dan agresif menekankan merk penjualan, kelebihannya dibandingkan dengan produk sejenis ataupun bagaimana kegunaanya bagi konsumen dan lain-lain.

b. Tahap Pertumbuhan

Tahap pertunbuhan ditunjukan dengan meningkatnya volume penjualan dengan cepat karena produk sudah menempatkan pada segmen pasar yang sesuai. Usaha yang dilakukan dalam tahap ini adalah menurunkan kegiatan promosinya untuk diganti dengan memperluas dan meningkatkan distribusi ke daerah-daerah (lokasi-lokasi segmen pasar) yang belum dimasuki atau kegiatan promosi digantikan dengan persaingan harga dengan perusahaan pesaing.

Pada tahap ini bermunculan perusahaan-perusahaan pesaing yang mencoba merebut segmen pasar yang kita kuasai dengan menggunakan strategistrategi yang dengan perlahan dan pasti dapat menggeser kedudukan perusahaan yang lebih dulu masuk pasar.

c. Tahap kedewasaan dan kejenuhan

Tahap kedewasaan merupakan titik puncak kejayaan perusahaan yang ditunjukan dengan peningkatan volume penjualan yang sangat tinggi. Pada tahap ini produk perusahaan sudah dikenal dengan baik oleh konsumen, sehingga usaha promosi amat sedikit peranannya dalam meningkatkan atau menambah volume penjualan. 
Tambahan volume penjualan sudah dilakukan sedangkan bagian pasar yang kita kuasai sudah banyak yang dimasuki produk-produk pesaing yang sedikit demi sedikit mulai mengikis segmen pasar kita, ditambah lagi dengan konsumen sudah mulai melirik produk sejenis lainnya yang sekiranya mempunyai keunggulan lebih banyak atau dengan kata lain konsumen sudah mulai jenuh dengan produk yang kita jual

\section{d. Tahap kemunduran/penurunan}

Akibat buruk perilaku konsumen tersebut menurunkan volume penjualan perusahaan sehingga perusahaan harus cepat-cepat mengambil kebijaksanaan agar perusahaan tidak bangkrut.

Adapun kebijaksanaan yang akan di ambil oleh perusahaan pada umumnya terdiri dari 2, yaitu :

1) Menghentikan produk yang sudah tidak dapat bersaing dengan digantikan oleh barang yang benar-benar baru dan lain dibandingkan dengan produk lama. Kebijaksanaan ini dapat berjalan dengan lancar asalkan perusahaan mempunyai tenaga yang punya kemampuan dalam membuat motivasi baru, kreasi, atau menciptakan barang yang akan menggantikannya.

2) Tetap mempertahankan barang lama tetapi memperbaharui atribut-atribut lamanya baik dari segi kemasan atau dapat juga menonjolkan kelebihan lain.
Kalau alternatif ini tidak dapat dilakukan perusahaan harus dapat membuat barang yang benar-benar baru yang memerlukan penelitian dari awal baik dari segi mutu, merk dagang, pembungkus, cara mendistribusikan dan lain-lain.

\section{Pembungkus barang}

Bungkus barang merupakan pertimbangan ke dua setelah produk yang sejenis ternyata mempunyai kualitas yang sama kualitas yang sama, rasa yang sama atau kegiatan yang relatif berbeda. Maka bagi pembeli yang merasa bingung dengan berbagai merk tersebut akhirnya akan mempertimbangkan bungkus luar produk yang akan dipilih. Oleh karena itu bungkus juga memegang peranan penting dalam penjualan produk.

Untuk membuat bungkus agar menarik pembeli maka perusahaan harus mempertimbangkan dari berbagai aspek baik aspek ekonomis, keindahan maupun praktisnya.

Adapun hal-hal yang perlu diperhatikan dalam pembungkusan diantaranya:

a. Bungkus yang membangkitkan hasrat untuk membeli.

b. Bungkus yang mudah diingat.

c. Bungkus yang tidak menambah harga jual sehingga tidak dapat besaing dengan produk sejenis yang lain.

d. Bungkus di design agar dapat menjaga mutu barang, memudahkan 
pengangkutan, penyimpanan, penyusunan di rak took, atau memmpunyai kegiatan setelah dipakai habis (ada kegiatan ganda).

\section{Merk Barang}

Merk barang yang dinyatakan dengan kata-kata saja atau disertai dengan gambar tertentu untuk mempertegaskan adalah sangat penting bagi perusahaan untuk membedakan perusahaan yang satu dengan yang lain. Dengan melihat merk seseorang yang sudah menggemari atau fanatic terhadap rasanya, mutunya atau keadaanya tidak akan nemilih lagi dalam memilih lagi dalam membeli barang cukup hanya dengan melihat gambar tertentu atau kata-kata tertentu dalam suatu prroduk menganggap sudah cukup memutuskan untuk membeli.

Dengan merk yang sudah menjadi langganan pemakai dapat menghemat waktu dalam membeli karena dapat menyuruh orang lain untuk membelinya (praktis) dan membuat anggaran tertentu dalam memakainya. Banyaknya manfaat yang dapat diperoleh konsumen ini ternyata terlihat juga oleh produsen sehingga sering sekali produsen menggunakan merk tersebut sebagai salah satu strategi pemasarannya dengan jalan perusahaan memproduksi barang yang tidak terlalu berbeda setiap memakai berbagai merk, hal ini dilakukan untuk menguasai pasar.

\section{Strategi Harga}

Menurut menurut Alex S Nitisemito (1991:55) Harga diartikan sebagai nilai suatu barang atau jasa yang diukur dengan sejumlah uang dimana berdasarkan nilai tersebut seseorang atau perusahaan bersedia melepaskan barang atau jasa yang dimiliki kepada pihak lain. Harga merupakan satuan moneter atau ukuran lainnya (termasuk barang dan jasa) yang ditukarkan agar memperoleh hak kepemilikan atau penggunaan suatu barang atau jasa, Tjiptono (2001 : 151). Dan harga merupakan unsur satu - satunya dari unsur bauran pemasaran yang memberikan pemasukan atau pendapatan bagi perusahaan di banding unsur bauran pemasaran yang lainnya (produk, promosi dan distribusi).

Strategi penetapan harga menjadikan tantangan yang semakin meningkat untuk banyak perusahaan, karena deregulasi, informasi dari pembeli, persaingan global yang kompetitif, pertumbuhan pasar yang lambat dan peluang perusahaan untuk meningkatkan posisi pasarnya. Harga berdampak pada kinerja keuangan perusahaan dan berpengaruh penting pada nilai penempatan merek di mata pelanggan. Harga juga mencermikan suatu ukuran kualitas dari suatu produk.

Harga merupakan salah satu dari empat variabelkeputusan strategi utama yang dikendalikan oleh manajer pemasaran. 
Keputusan penetapan harga memengaruhi jumlah penjualan yang dilakukan oleh perusahaan dan berapa banyak pendapatan yang diperoleh. Harga adalah sesuatu yang harus diberikan kepada pelanggan untuk mendapatkan keunggulan yang ditawarkan oleh bauran pemasaran perusahaan. Jadi, harga melakukan peranan langsung dalam dalam membentuk nilai pelanggan.contoh: ragged mountain menginginkan para pelangannya mengetahui bahwa harganya adalah nilai yang bagus dibandingkan dengan apa yang mereka dapat di resor ski lainnya.

\section{Tujuan promosi}

Menurut Fandy Tjiptono (1997 : 221) tujuan utama dari promosi yaitu:

1. Menginformasikan (informing) dapat berupa menginformasikan pasar mengenai keberadaan suatu produk baru, memperkenalkan cara pemakaian yang baru dari suatu produk, menyampaikan perubahan harga kepada pasar, menjelaskan cara kerja suatu produk, menginformasikan jasa-jasa yang disediakan oleh perusahaan, meluruskan kesan yang keliru, mengurangi ketakutan atau kekhawatiran pembeli, membangun citra perusahaan.

2. Membujuk pelanggan sasaran (persuading) untuk membentuk pilihan merek, mengalihkan pilihan ke merek tertentu, mengubah persepsi pelanggan terhadap atribut produk, mendorong pembeli untuk belanja saat itu juga, mendorong pembeli untuk menerima kunjungan wiraniaga (salesman).

3. Mengingatkan (reminding) dapat terdiri atas mengingatkan pembeli bahwa produk yang bersangkutan dibutuhkan dalam waktu dekat, mengingatkan pembeli akan tempat-tempat yang menjual produk perusahaan, membuat pembeli tetap ingat walaupun tidak ada kampanye iklan, menjaga agar ingatan pertama pembeli jatuh pada produk perusahaan.

Secara singkat promosi berkaitan dengan upaya untuk mengarahkan seseorang agar dapat mengenal produk perusahaan, lalu memahaminya, berubah sikap, menyukai yakin kemudian akhirnya membeli dan selalu ingat akan produk tersebut.

Jenis-jenis promosi penjualan yang dilakukan oleh perusahaan sangat beragam, tergantung dari situasi konsumen atau kondisi pada saat itu. Adapun jenis promosi penjualan yang dapat dilakukan adalah:

1. Pemberian harga khusus (special price) atau potongan harga (discount) untuk produk tertentu ;

2. Pemberian undian kepada setiap pelanggan yang membeli dalam jumlah tertentu; 
3. Pemberian cinderamata serta kenangkenangan lainnya kepada konsumen yang loyal; dan

4. Promosi penjualan lainnya.

Promosi yang ketiga adalah publisitas. Publisitas merupakan kegiatan promosi untuk memancing pelanggan melalui kegiatan, seperti pameran, bakti sosial, serta kegiatan lainnya. Kegiatan publisitas dapat meningkatkan pamor perusahaan di mata para konsumennya. Oleh karena itu, promosi melalui publisitas perlu diperbanyak. Kegiatan promosi yang keempat adalah penjualan pribadi atau personal selling.

Dalam dunia bisnis penjualan pribadi secara umum dilakukan oleh salesman dan salesgirldengan cara door to door.

\section{METODE PENELITIAN}

Jenis penelitian ini bersifat deskriptif, maka penelitian ini diharapkan dapat menjelaskan fenomena yang ada, terutama yang berkaitan dengan Strategi Marketing PMB USB Ditengah Pandemi Covid 19.

\section{HASIL PENELITIAN DAN PEMBAHASAN}

Situasi pandemi seperti sekarang ini mengharuskan setiap orang merubah pola rutinitasnya. Aktivitas pekerjaan, belajar, belanja, bahkan berjualan pun sebisa mungkin dilakukan di rumah.

Masa sekarang menjadi masa yang tidak ada kepastian dan media harus siap dalam segala hal. Ia berbagi pengalaman, bahwa media yang dipimpinnya selama wabah ini melakukan tiga strategi komunikasi. Yang pertama, media sebagai pembawa pesan yang baik dengan menyebarkan informasi yang kredibel dan kontekstual. Kedua, menjadi penghibur yang baik dengan menyediakan program hiburan dan pendidikan. Dan terakhir, sebagai pemicu sosial yang mendorong setiap orang untuk membantu orang lain.

Media sebagai pembawa pesan menurut catatan harus memperhatikan halhal berikut. Pertama, mengetahui perannya. Media dapat memainkan peran secara umum, tetapi tidak semua komunikasi harus terkait dengan wabah virus corona dan bangun kampanye untuk membantu orang mengatasi situasi. Dua, konteks yang lebih praktis. Buat konten untuk membantu orang mengatasi kebutuhan mereka. Tunjukkan nilai merk sebagai media yang memahami publik. Ketiga, berita positif. Sorot berita positif sebagai bagian dari kampanye media. "Komunikasikan kepada audiens bahwa kita di sini sebagai teman untuk menjaga dan mendukung mereka. Hubungkan setiap orang hanya lewat rumah," jelasnya. 
Media sebagai penghibur dapat melakukan dua strategi komunikasi. Pertama, temukan titik sakitnya. Kehidupan rumah akan menjadi menyakitkan, membosankan, kesepian, tidak produktif, tanpa olahraga, dan sebagainya. Maka, media dapat membuat aktivitas kampanye yang menjadi pelipur lara para audient tadi. Kedua, menciptakan kebiasaan baru.

Selama isolasi diri, maka kemungkinan banyak audiens akan menghabiskan waktu di depan telepon pintarnya. Untuk itu, penting bagi media untuk membuat outlet positif berupa hiburan, pendidikan, atau hal lain yang mendorong para penontonnya untuk terus terkoneksi dengannya, dan berkat menonton konten tersebut dapat mendorong menjadi produktif. Contohnya seperti bagaimana cara bersilaturahmi bagi anak kos dan bagaimana olahraga yang bisa dilakukan selama di rumah saja.

Media sebagai pemicu sosial, penting bagi media untuk memeriksa merknya apakah selama ini telah berperan dalam masyarakat. Untuk mengetahuinya, dapat melalui kampanye sosial yang dapat menjadi tolok ukur untuk memeriksa pengaruh media tersebut.

Memperlihatkan nilai media bukan hanya kepasa masyarakat, namun juga kepada rekan kerja dan klien media lain. Lalu, strategi lain dalam pemicu sosial dapat dilakukan dengan mengubah program hiburan menjadi program sosial yang masif ehingga dapat memicu orang untuk membantu orang lain. "Kami bersama Anda, kami mengubah diri kami sehingga kami dapat saling melengkapi. Untuk mengubah gangguan menjadi peluang," tutupnya.

Survei terhadap 400 pembeli dan merek media, 74\% akan lebih buruk untuk iklan daripada krisis keuangan 2008. Seperempat dari mereka telah menghentikan semua iklan untuk kuartal pertama dan kedua, sementara $46 \%$ lainnya telah menyesuaikan pengeluaran selama tahun ini. Sangat bahaya jika suatu brand lalu memutus komunikasinya dari pelanggan. Hal ini dapat membuat lupanya value perusahaan di mata mereka. "Sekarang saatnya untuk start game, karena tidak banyak orang yang bisa buat konten di luar, maka manfaatkan untuk ningkatin skill dengan keterbatasan ini.

Tiga strategi managemen di masa sekarang khususnya dalam PMB Universitas Sangga Buana Bandung. Pertama, bantuan - berada untuk pelanggan. Jadikan ini sebagai kesempatan untuk lebih dekat dengan pelanggan. Komunikasikan bahwa masa sekarang pengiriman barang hanya dapat dilakukan dua hari sekali misalnya, jadi tidak bisa setiap hari mengirim barang seperti pasa normal sebelum pandemi. Buat kehangatan dengan para pembeli, misal di saat sekarang 
orang lebih nyaman berkomunikasi lewat whatsApp darimana e-mail karena dirasa lebih santai. Kita juga dapat lakukan solusi lain agar tetap dikenal audiens dengan cara pemberian bebas ongkir.

Kedua, jaminan, orang sekarang lebih ensecure karena virus corona. Maka kita dapat membuat konten dengan melihatkan bagaimana prosedur kita dalam membungkus atau mengirim barang pesanan sesuai dengan protokol dan aturan pemerintah. Himbauan ini dapat dipublish seperti memakai masker, menyemprotnya dengan disinfektan, memakai hand sanitizer, dan sebagainya.

Ketiga, aksi-bawa pengalaman ke platform kami. Termasuk strategi pre-order atau pengiriman gratis. Buat strategi komunikasi yang menarik audiens. Karena jangan sampai konsumen hanya memikirkan pembeliannya saja tanpa menerima value dari brand. Agar tidak terlupakan oleh pelanggan, sebagai contoh perusahaan hotel dan pariwisata lainnya. Dapat membuat startegi marketing dengan menjelajah mimpi-mimpi setiap orang untuk berkunjung ke berbagai tempat yang menarik setelah selesainya pandemi ini. Tawarkan hal-hal yang unik, seperti diskon beberapa persen jika memesannya sekarang.

Pertimbangkan cara-cara merk Anda dapat membantu. "Tujuan marketing itu ada dua, pertama mempresuasi orang agar tertarik dan beli produk. Kedua, menjaga brand value. Bagaimana kita mengkomuniksikan misi-misi kepada orang agar ngerti value kita," tambahnya.

Lima prinsip untuk bertindak di media sosial selama Covid-19, yakni: (1) Dengarkan dulu. Dengarkan apa yang dikatakan konsumen, lalu tanggapi. (2) Jadilah sensitif. Evaluasi kembali konten untuk nada dan pesan. (3) Bersikap transparan. Berkomunikasi secara terbuka dan menerima umpan balik. Adaptasikan strategi Anda. Adaptasikan strategi Anda berdasarkan perilaku baru. (5) Bangkitlah untuk kesempatan ini Persebaran wabah virus corona atau COVID-19 cukup berdampak masif di sektor pendidikan. Termasuk di lingkungan perguruan tinggi.

Sejumlah perguruan tinggi mengeluarkan surat edaran yang berisi langkah-langkah pencegahan persebaran COVID-19, mulai dari menunda seremoni wisuda hingga memberlakukan sistem kuliah daring atau online.

Musim penerimaan mahasiswa baru yang sudah menjadi agenda wajib bagi perguruan tinggi. Lalu, bagaimana cara perguruan tinggi menarik minat calon mahasiswa baru di situasi penyebaran wabah COVID-19 atau virus corona ini. 


\section{Permudah Cara Penerimaan}

\section{Mahasiswa Baru}

Hal pertama yang harus Anda lakukan adalah mempermudah jalur penerimaan mahasiswa baru, karena disituasi saat ini tidak memungkinkan untuk keluar rumah apalagi para calon mahasiswa melakukan pendaftaran di kampus. Yang bisa dilakukan kampus adalah menerapkan sesegera mungkin penerimaan mahasiswa baru dengan cara online atau sering dikenal dengan PMB online. PMB online ini sangat memudahkan para pencari kampus dan juga memudahkan perguruan tinggi.

\section{Permudah Proses Pembayaran}

Setelah mempermudah proses penerimaan mahasiswa baru, hal kedua yang harus dilakukan kampus adalah mempermudah proses pembayaran, karena pembayaran yang menyulitkan akan membuat calon pendaftar enggan melakukan pembayaran dan akhirnya tidak jadi daftar di kampus anda.

Saat ini zaman serba digital, pembayaran online bisa menjadi solusi yang tepat untuk situasi sekarang ini, tidak mengharuskan tatap muka untuk melakukan pembayaran. Pembayaran online memang menjadi solusi pas, jadi saatnya kampus anda harus menerapkan pembayaran online.

\section{Gunakan Digital Marketing untuk} Promosi Kampus

Setelah mempermudah proses penerimaan dan pembayaran, yang harus anda lakukan selanjutnya adalah Promosi. Karena di situasi sekarang promosi dengan konvensional tidak memungkinkan, salah satu solusinya adalah memanfaatkan teknologi digital yang mudah dijangkau oleh banyak orang. Berikut yang bisa Anda lakukan dengan promosi dengan digital marketing:

\section{a. Gunakanlah website agar lebih cepat dikenal}

Cara ini merupakan strategi promosi yang sudah semestinya digunakan kampus disitusi yang serba mengandalkan online. Perguruan tinggi bisa memakai website untuk company profile, dimana website ini adalah letak utama untuk memasang bermacam informasi, fasilitas, jurusan, biaya dan lain lain.

Kelebihan lain sekiranya kampus miliki website adalah mampu dipercaya, mampu tunjukkan prestasinya, galeri, organisasi dan dokumentasi dokumentasi lain.

\section{b. Buatlah iklan video di youtube}

Mengaitkan pemakaian teknologi yang tambah besar, para remaja biasanya bakal segera mensurvey melalui video video yang terupload di youtube daripada datang secara segera ke perguruan tingginya. Strategi pemasaran perguruan tinggi swasta ataupun negeri seperti ini sering dilakukan.

Ada dua cara promosi via youtube untuk kampus yaitu mampu memakai yang 
berbayar ataupun terhitung mampu yang gratis, dengan meng-upload video kampus didalam jumlah yang memadai banyak tidak cuman itu disertai optimasi kata kunci / kata kunci.

\section{c. Konten marketing dan SEO optimasi}

Konten marketing adalah tips jitu untuk menarik pembaca di Google Search Engine, dikarenakan rata rata seseorang pasti bakal jalankan survey tentang kampus yang bagus menurut kebutuhannya. Konten marketing adalah postingan / posting artikel yang berisi konten marketing yang di optimasi memakai teknik SEO.

Mungkin banyak yang belum memahami perihal tersebut, dikarenakan siasat seperti ini sering digunakan oleh kalangan pembisnis besar tetapi tersedia terhitung yang jalankan pada segi pemasaran sekolah dan perguruan tingginya.

\section{d. Manfaatkan platform pencarian}

\section{kampus}

Memanfaatkan platform pencarian kampus seperti platform Maukuliah.id merupakan cara yang paling tren saat ini, karena saat ini lulusan SMA/SMK rata-rata mereka mencari informasi tentang kampus di platform-platform seperti ini.

Mereka menyediakan informasi yang lengkap tentang kampus dan jurusan, jadi memudahkan para pencari siswa dalam mencari jurusan dan kampus yang diinginkan. Jadi kampus Anda bisa memanfaatkan platform ini untuk tempat promosi kampus.

\section{PENUTUP}

Memang saat ini kita sedang mengalami situasi yang sulit, namun proses penerimaan mahasiswa baru juga harus terus berjalan demi keberlangsungan kampus dan juga pembelajaran di Indonesia khususnya di USB.

Dengan teknologi kampus bisa memudahkan penerimaan mahasiswa baru, memberikan pelayanan yang serba canggih, seperti PMB, pembayaran, keakademikan, pembelajaran dll.

Setelah mempermudah proses penerimaan dan pembayaran, yang harus dilakukan selanjutnya adalah Promosi. Karena di situasi sekarang promosi dengan konvensional tidak memungkinkan, salah satu solusinya adalah memanfaatkan teknologi digital yang mudah dijangkau oleh banyak orang. Berikut yang bisa dilakukan dengan promosi dengan digital marketing: Gunakanlah website agar lebih cepat dikenal, Buatlah iklan video di youtube, Konten marketing dan SEO optimasi, Manfaatkan platform pencarian kampus.

\section{DAFTAR PUSTAKA}

Fehr, A.R., Perlman, S. (2015). Coronavirus: An Overview of Their Replication and Pathogenesis. Methods Mol Biol. 2015. 
Feroniko,

antoni, dkk.2013, http:www.academia.edu/53 19440/Makalah_Manajemen_pemasa ran_Pengembangan_strategi_dan_pro gram_penetapan_harga diakses pada tanggal 2 November 2018

Gruenwald, G. 15. Seri Pemasaran dan Promosi, Pengembangan Produk Baru, PT Alex Media Komputindo, Jakarta

Joseph, P. Cannon., William. D. Perreault., dan E. Jerome McCharty. Pemasaran Dasar. Terjemahan oleh Diana Angelica dan Ria cahyani. 2019. Jakarta: Salemba Empat,

Keegan, Warren J. 2016, Manajemen Pemasaran Global : Alih Bahasa, Alexander Sindoro Jilid 1, Jakarta: Prenhallindo.

Korsman, S.N.J., van Zyl, G.U., Nutt, L., Andersson, M.I, Presier, W. (2012). Viroloy. Chins: Churchill Livingston Elsevier.

Kotler, P. 2005. Manajemen Pemasaran; Analisa, Perencanaan, Implementasi dan Pengendalian. Jilid I, edisi kedelapan, Penerbit Salemba Empat, Jakarta.

Philip Kotler,(2003): "Marketing Manajemen", 11th Edition, Prentice Hall Inc.

Perhimpunan Dokter Paru Indonesia. (2020). Panduan Praktik Klinis: Pneumonia 2019-nCoV. PDPI: Jakarta

Simamora, henry (2000) : "Manajemen Pemasaran Internasional 2", Edisi soft cover, Jakarta: Salemba Empat.
Widyatmini, 2005, Pengantar Bisnis,Cetakan ke IV edisi 1, seri, Depok, Seri Diktat Kuliah : Gunadarma 